\title{
Systematic stability analysis, evaluation and testing process, and platform for grid-connected power electronic equipment
}

\author{
Z. Zhang®, R. Schürhuber, L. Fickert, K. Friedl, G. Chen, Y. Zhang
}

\begin{abstract}
The proportion of grid-connected power electronic equipment is already large enough to influence the dynamic characteristics of the modern power system. Ensuring the stability of grid-connected power electronic equipment in all relevant situations is one of the foundations for reliable power system operation. In contrast to conventional rotating machines, the stability of power electronic devices mostly depends on the applied control strategy, and a large diversity of different complex control strategies are in practical use. Also, the investigation of stability of such systems needs to take into account the non-linear behaviour of the power electronic equipment. These are the main reasons why the system behavior of grid-connected power electronic equipment cannot be reproduced satisfactorily when aplying a single method of stability analysis, evaluation and testing method. During the last years, faults which led to tripping of converters due to stability problems occurred frequently even though standardized fault compliance tests were performed on these converters. In this paper these stability issues are analyzed. Also, a three-dimensional stability analysis method is suggested in order to comprehensively cover system behavior. The three dimensions are the time/scale dimension, the equipment number dimension and the local or global range of the stability analysis dimension. Based on this three-dimensional framework, this paper proposes a stability evaluation as well as a test process applying a hardware-in-the-loop test concept. Through the verification and testing of the stability of the actual grid-connected power electronic equipment, the method proposed in this paper is verified for up-to-date equipment.
\end{abstract}

Keywords: converter stability; transient stability; hardware-in-the-loop test; Lyapunov method; domain of attraction

Systematische Stabilitätsanalyse, Bewertungs- und Testprozess und Plattform für netzgekoppelte leistungselektronische Geräte.

Der Anteil der netzgekoppelten leistungselektronischen Geräte ist bereits groß genug, um die dynamischen Eigenschaften des Energiesystems zu beeinflussen. Die Gewährleistung der Stabilität von netzgekoppelten leistungselektronischen Geräten in allen relevanten Situationen ist eine der Grundlagen für den zuverlässigen Betrieb von Energiesystemen. Im Gegensatz zu konventionellen rotierenden Maschinen hängt die Stabilität der leistungselektronischen Geräte primär von der angewandten Steuer- und Regelungsstrategie $a b$, in der Praxis existiert eine große Vielfalt unterschiedlicher, meist komplexer, Regelungsstrategien. Bei der Untersuchung der Stabilität solcher Systeme muss das nicht lineare Verhalten der leistungselektronischen Geräte berücksichtigt werden. Die Vielfalt an implementierten Strategien, in Kombination mit den Anforderungen eines hohen Detaillierungsgrades bei der Modellierung, sind die Hauptgründe dafür, dass das Stabilitätsverhalten von netzgekoppelten leistungselektronischen Geräten durch Anwendung bisheriger Prüfmethoden nicht zufriedenstellend reproduziert werden kann. In den letzten Jahren traten häufig Fehler auf, die aufgrund von Stabilitätsproblemen zum Auslösen der Schutzeinrichtung der Umrichter führten und damit die Geräte ungewollt vom Netz trennten, obwohl diese Einheiten standardisierte Fehlerkonformitätstests erfolgreich bestanden hatten. In diesem Artikel wird diese Stabilität analysiert und auch eine dreidimensionale Stabilitätsanalysemethode vorgeschlagen, um das Systemverhalten umfassend zu untersuchen. Diese drei Dimensionen sind die Dimension der Zeitskala, die Dimension der Anzahl der Geräte und die lokale oder globale Reichweite der Dimension der Stabilitätsanalyse. Basierend auf diesem dreidimensionalen Rahmen wird ein Stabilitätsbewertungs- und Testprozess vorgeschlagen, welcher ein Hardware-in-the-Loop-Testkonzept verwendet. Die Methode wird vorgestellt und es werden Ergebnisse präsentiert, welche die praktische Anwendbarkeit verifizieren.

Schlüsse/wörter: Konverterstabilität; transiente Stabilität; Hardware-in-the-Loop-Test; Lyapunov-Verfahren; Attraktionsbereich

Received July 6, 2020, accepted November 3, 2020, published online November 16, 2020

(c) The Author(s) 2020

\section{Introduction}

The penetration of modern power system, with components connected via power electronic devices, thus converters, has been increasing tremendously during the last years. With inheriting a large number of high inertia generation equipment, those systems also were designed to handle faults based on such equipment, and so
Zhang, Ziqian, Institute of Electrical Power Systems, Graz University of Technology, Graz, Austria (E-mail: ziqian.zhang@tugraz.at); Schürhuber, Robert, Institute of Electrical Power Systems, Graz University of Technology, Graz, Austria; Fickert, Lothar, Institute of Electrical Power Systems, Graz University of Technology, Graz, Austria; Friedl, Katrin, Institute of Electrical Power Systems, Graz University of Technology, Graz, Austria; Chen, Guochu, Shanghai Dianji University, Shanghai, China; Zhang, Yongming, Shanghai Dianji University, Shanghai, China 
the increasing power electronic equipment result in large challenges to the stability of power systems [1, 2].

The stability of power electronic equipment is very sensitive to the applied control strategies. Due to the non-linear behavior of the control path and wide time-scale dynamics [3], the complexity of stability analysis is increased. The complexity results from three different dimensions. These are firstly the penetration number of power electronic equipment investigated in the analysis [2], secondly the timescale of dynamic behavior to be investigated [3] thirdly the local or global range of system behavior $[4,5]$.

\subsection{Dimension 1: number of power electronic equipment}

Complexity caused by diversity of equipment also exists in the conventional power system [6], but compared to power electronic equipment, the models of traditional power equipment are much more unified and standardized, unlike power electronic equipment, which varies greatly both from circuit topology and control concepts [7]. This diversity causes manifold interactions between equipment, making the dynamic behavior more complex. In this dimension, stability analysis can be divided into three levels: single equipment system, small scale system, and large scale system.

"Single equipment system" refers to a single power electronic equipment. It can be a wind turbine, a photovoltaic converter, a HVDC converter, etc. [8]. This level focuses on the stability of an equipment itself, or the stability of an equipment with a power system, containing no other power electronic equipment.

"Small scale system" refers to the local power system composed of several power electronic equipment. It can be a micro-grid system [9], a wind farm [10], one or several photovoltaic power plants, etc.

"Large scale system" refers to the power system composed of several local area systems. It can e.g. be a power system of a certain region or a power system of a certain country [11].

\subsection{Dimension 2: time-scale}

The solid-state switching elements of power electronic equipment operate in the time scale of one hundred microseconds. Other control units, such as DC-link control or turbine governors, operate in the range of 0.1 seconds to 10 seconds [3]. So the power electronic equipment has a wide time-scale of the system behavior [12-15], leading to descriptions involving multiple time scales. For analyzing stability, the time-scale dimension can be divided into five levels: mechanical, DC link, AC RMS, AC Electromagnetic Transients (EMT) and side band level.

"Mechanical time-scale" refers to the time constant of the mechanical part of the system. This time-scale usually lies within the range of seconds, e.g., pitch control and yaw control of wind power generation [16]; speed control of electrical traction [17]; humidity, temperature and oxygen content control of proton-exchange membrane of fuel cells [18].

"DC link time-scale" refers to the time constant of the DC link and power control. This time is usually in the 0.1 second range [19, 20].

"AC RMS time-scale" refers to the time constant of the synchronization control. This time-scale is usually in the range of $0.01 \mathrm{sec}-$ onds to 0.1 seconds [21], which is close to the fundamental cycle of power frequency.

"AC EMT time-scale" refers to the time constant of the voltage and current control. This time is usually below 0.01 seconds [22, 23].

"Sideband signal time-scale" refers to the time-scale near the carrier frequency of the power semiconductor. This time scale is usually below 0.001 second I [24].

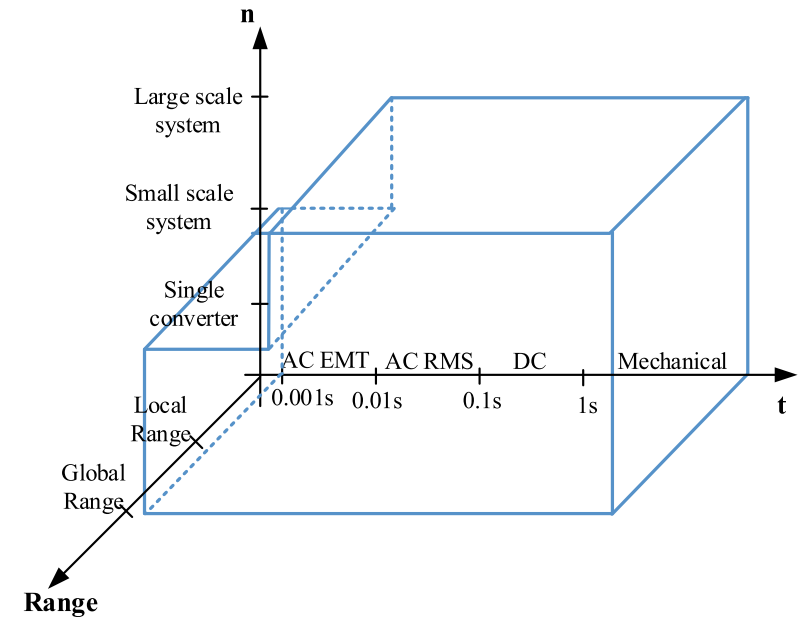

Fig. 1. Three-dimensional system stability analysis framework (Color figure online)

1.3 Dimension 3: analysis range of system behavior In normal operation of power electronic equipment, each state variable should be located at its stable equilibrium point. The stability analysis of the system around an equilibrium point is called the local stability analysis [4]. When the power electronic equipment is externally or internally disturbed [25] [26, 27], some state variables will leave the initial stable equilibrium point and come to a new equilibrium point or divergence $[28,29]$. The stability analysis of this process is called the global stability analysis. Global in this paper refers to the range that the system can reach and is relative to a single equilibrium point.

In the local stability analysis, the system needs to be linearized near the equilibrium point. The linearized system can only represent the behavior near the equilibrium point, and cannot describe the behavior of the system far from the equilibrium point.

Global stability analysis takes the nonlinearity of the system into account. The qualitative global analysis uses a method similar to the phase portrait method $[25,26]$. The qualitative analysis method intuitively determines the transient stability. The estimation of domain of attraction method [30] [31] is used to quantify the global analysis.

The remaining sections of this paper are arranged as follows. Based on the concept of three-dimensional stability analysis method, Sect. 2 proposes a set of stability analysis methods of power electronic equipment. Section 3 gives the corresponding evaluation and testing process. Section 4 studies the selection method of test cases and detailed stability evaluation methods, respectively. Section 5 practices the stability evaluation and test process. Section 6 summarizes the full paper.

\section{Method for stability analysis, evaluation and test of power electronic equipment}

\subsection{Framework of stability analysis}

A framework of stability analysis for power electronic equipment is proposed in this paper, as shown in Fig. 1. This framework is obtained from combining the three dimensions of number of power electronic equipment, time-scale and analysis range of system behavior.

A complete stability analysis of power electronic equipment must be across time-scales, " $\mathbf{t}$ " axis in Fig. 1. The stability analysis needs to consider all the control units of the power electronic equipment 
and the coupling relationship between them. Individual analysis of a certain time-scale cannot reflect the complete characteristics. Furthermore, a complete stability analysis must also across different "quantity ranges", " $\mathbf{n}$ " axis in Fig. 1, so the stability analysis needs to consider the behavior and interaction between equipment. The analysis of one single power electronic equipment cannot reflect its complete characteristics in a power system. Finally, a complete stability analysis must take into account both local and global range stability of the system, "Range" axis in Fig. 1.

The scope of research of this paper is visualized in Fig. 1 with the blue volume. For the stability analysis of the large scale system in the AC EMT time-scale, due to the transformer and the long transmission line, the transmission of influence of the AC EMT is reduced, the interaction in this level is weak [32]. Therefore, this level of system stability analysis is beyond the scope of this paper. Similarly, due to the influence of filters and transmission lines, the interaction of equipment in the time-scale of sideband signals is very weak, so the system stability analysis of this time-scale is not within the scope of this paper.

\subsection{Stability analysis method}

Based on the framework of three-dimensional stability analysis, this paper presents a set of stability analysis methods for power electronic equipment. The basic concepts are from few devices to many devices, from slow time scales to fast time scales and from local stability analysis to global stability analysis.

From few to many devices: we start with the analysis of the stability of a single power electronic equipment, and gradually add other equipment to the system, which will affect the equipment to be finally considered.

From slow to fast times scales: When analyzing a single device, start from the slower time-scale. According to the characteristics of the cascade control, the time constant of the upstream control unit is larger than that of the downstream control unit. So, the upstream has a greater influence on the downstream than the downstream has on the upstream. When analyzing system behavior, the upstream control unit must be given priority. The downstream control unit can be idealized according to the analysis requirements.

From local to global stability analysis: Stability analysis of the system should start from steady state, and gradually expand the range of analysis. For example, the analyzation process should focus on an equilibrium point, afterwards close to the equilibrium point, until the global stability analysis range is reached.

The flow of a comprehensive stability analysis is as follows:

1. Describe the hardware and control algorithm of a single equipment and power system.

2. Find the stable equilibrium point of a single equipment and model it linearly.

3. Analysis of the stability of a single equipment, then extended the analysis to small scale system and large scale system.

4. Model large-signal models of one single equipment.

5. Qualitative and quantitative analysis of non-linear large-signal models.

\section{Stability evaluation and testing process}

\subsection{Present stability evaluation and testing process}

The present evaluation and testing process of power electronic equipment is divided into two separate parts, as shown in Fig. 2.

1. type test,

2. certification and stability evaluation.

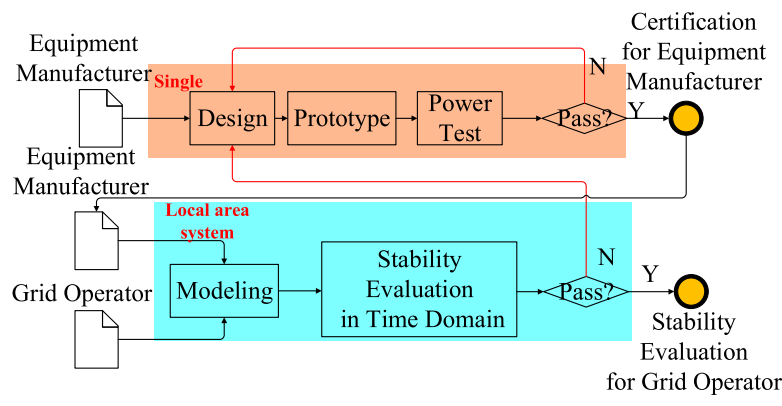

Fig. 2. Current stability evaluation and testing process (Color figure online)

In Fig. 2, the orange part represents the type test and certification process for power electronic equipment [33] [34]. In this process, the stability test investigates a single piece power electronic equipment and does not consider the interaction between the power system.

The blue part in Fig. 2 shows the stability evaluation of the model process $[35,36]$. A time-domain simulation is performed with the power electronic equipment and either a standard grid model or a specific grid model representing the grid is investigated. The simulation results are used to evaluate the performance and stability of the power electronic equipment in combination with the power system. With this method, it is difficult if not impossible to evaluate power electronic equipment integrated into a large-scale grid due to the high computational performance needed for time-domain simulations. Therefore, in this process the stability of power electronic equipment is evaluated just with models of limited scale power systems, such as a local grid model.

Because neither type testing nor model evaluation can accurately reflect the behavioral characteristics of power electronic equipment, it has led to repeated unstable phenomena of power system in recent years [37-41].

In addition, due to the manufacturing period of physical prototypes, the entire product design-test process takes a lot of effort from the manufacturers point of view, resulting in higher costs and longer time spans until commission can take place.

\subsection{Proposed stability evaluation and testing process}

According to the three-dimensional framework in Fig. 1, this paper proposes a stability evaluation and test process for power electronic equipment. This process is based on hardware-in-the-loop testing, which can comprehensively evaluate and test the local and global range of stability on each time-scale from a single equipment to a wide area system. It can also speed up the testing and evaluation process and increase the credibility of testing and evaluation.

This evaluation and test process consists of three closely connected parts, as shown in Fig. 3:

1. pre-evaluation based on controller hardware-in-the-loop test [42],

2. type test and certification based on power hardware-in-the-loop test [43],

3. large scale system stability evaluation.

In Fig. 3, the blue part represents the pre-evaluation process based on controller hardware-in-the-loop (CHIL) test. The controller dominates the system's dynamic performance, so the test of the controller alone can reflect the system performance of power electronic equipment. This pre-evaluation process requires controller hardware, models of power hardware and also models for the grid. 


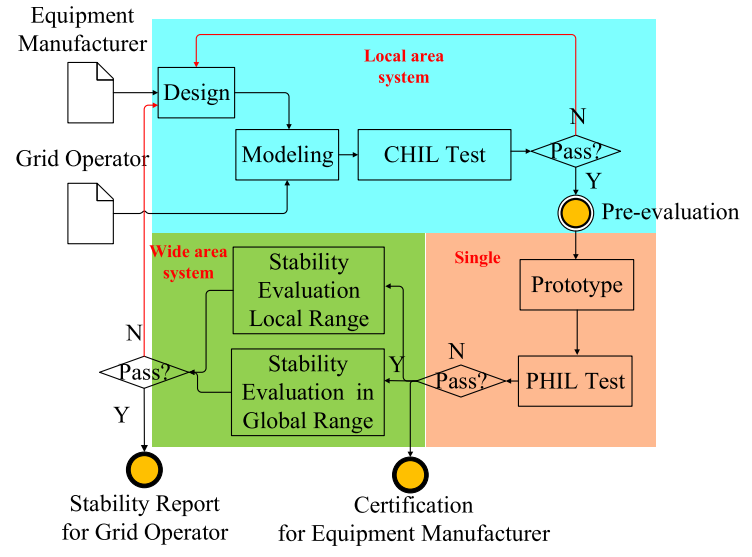

Fig. 3. Proposed stability evaluation and testing process (Color figure online)

The models are simulated in real time in a real-time simulation system. The controller controls the power hardware model in the realtime simulator and is connected to the grid model as well. By using this test method, one can also easily perform stability evaluation of several controllers in parallel, thus checking possible undesired interactions within the control. The test can cover all needed time-scales and grid scales, and can be used for both local and global stability ranges. This pre-evaluation process can carry out iterations and optimization in the early stages of product design, accelerating the cycle of product development, since only the controller of the power electronic equipment is needed for the test, which can easily be integrated in any lab equipment

The orange parts in Fig. 3 shows the type test and certification process based on power hardware-in-the-loop (PHIL) test. The type test of the prototype of power electronic equipment is a comprehensive assessment of the overall power electronic equipment. Compared with CHIL, the equipment under test of PHIL test contains all the components of power electronic equipment, such as power hardware, sensors, etc. Stability problems caused by sensor errors, electromagnetic interference, etc. can also be reproduced by PHIL tests. In addition, in order to reflect the performance of real power hardware parts, such as overcurrent, overvoltage capability, temperature rise and mechanical stress, it is necessary to perform PHIL test on the prototype. In the PHIL based type test process, the grid model and the mechanical part model are simulated in real time in the realtime simulation system. The complete power electronic equipment, thus the converter together with the controller, is connected with the grid model and the mechanical part model through the power amplifier and sensors. Such a test process can complete the test of various operating conditions in the test laboratory, such as different solar irradiance, different wind conditions, different power grid conditions, etc. Its stability testing also covers all scales from single equipment to small scale system, including all time-scales, local and global stability ranges. The result of the type test process is the certification of power electronic equipment for manufacturer, and can provide reliable raw data for subsequent large-scale system evaluation.

For distribution system operators (DSO) or transmission system operators (TSO), the stability evaluation of power electronic equipment in large-scale systems is necessary, as shown in Fig. 3 (green part). Due to the limitation of the computing power of the real-time simulator, large scale systems cannot be simulated in real time. Therefore, the stability evaluation of large scale systems can only be carried out

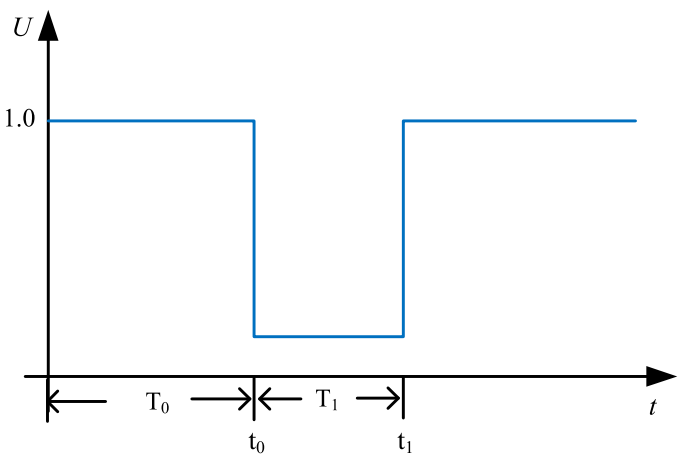

Fig. 4. Voltage amplitude curve of LVRT

on offline models of power electronic equipment, which rely on the analysis-based stability analysis and time-domain simulation as an auxiliary evaluation method. The test laboratory uses the test results to verify and calibrate the model provided by the manufacturer. The verified model will be used to evaluate the local stability and global stability of the large scale system. The result of this process is a stability report for DSO and TSO. Such a certification is mandatory according to current grid codes in order to operate generation equipment connected to the power grid, see e.g. [44-46].

In the proposed stability evaluation and testing process, manufacturers can accelerate their product development-test period. The grid operators can obtain a credible stability evaluation report through the verified model.

\section{Test cases and stability analysis methods}

The stability results of the power electronic equipment depend on specific fault test cases. In a standardized stability evaluation and test process, it is impossible to traverse the power electronic equipment with all fault test cases. Therefore, one or a few extreme fault testcases will be selected to test the power electronic equipment [33]. It is expected that the stability evaluation and test results of extreme fault test cases can cover all failure possibilities. However, since power electronic equipment is non-linear, the most severe fault test case in one index does not represent the most severe fault test case globally. In this section, methods for selecting suitable test cases and methods for stability evaluation that do not rely on test cases are proposed.

\subsection{Test case selection method}

In the stability evaluation and testing of fault ride-through ability, namely global stability analysis, one or a few specific fault test cases are used to investigate the response of power electronic equipment to faults. For example, in the current test standards [33-35], the failure case for the low voltage ride through (LVRT) capability test is described as follows: The output voltage of the power electronic device under test is required to experience the voltage curve shown in Fig. 4. The voltage dip generator can be a shunt impedance voltage sag generator (SIVSG) or an ideal voltage source, and the grid impedance is fixed and will not change during the test.

However, in a real grid fault, the grid impedance will change drastically due to the change in fault impedance and line impedance. Such changes will cause the system dynamic performance to be very different from the test results of the above test method. In order to give a suitable fault test case including fault impedance, line impedance, etc., the stability of the system based on global range should be clearly analyzed. 


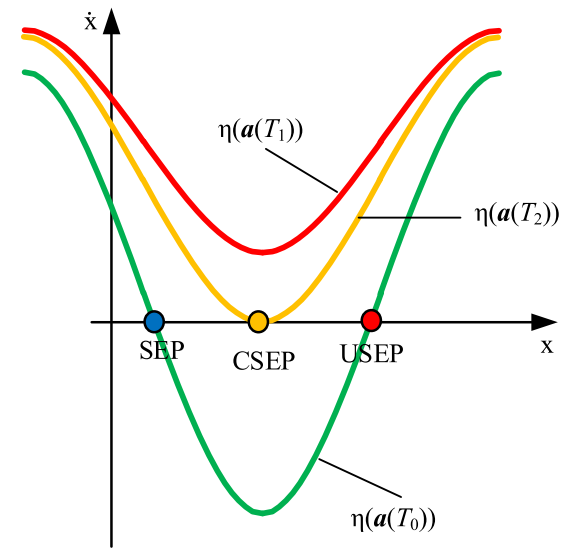

Fig. 5. Phase portrait (Color figure online)

When we conduct a large-signal analysis of the power electronic equipment-power system, we can obtain mathematical descriptions in the form of the nonlinear differential equations. These equations cannot be solved analytically. Therefore, a phase portrait like method [25-27] based on the analysis of the trajectory is adopted. It is the geometric expression of the trajectory of the dynamic system on the phase plane, as shown in Fig. 5.

Figure 5 shows the trajectory of operation point of the power electronic equipment-power system for three different grid configurations, the healthy grid case in the green curve, the fault grid case in the red curve and the critical grid case in the orange. Three different kinds of equilibrium points can be observed: stable equilibrium point (SEP), the unstable equilibrium point (USEP) and critical stable point (CSEP).

The position of the equilibrium points depends on the settings of power electronic equipment as well as on grid situation. It is located at the intersection of the trajectory and $x=0$. This is the control goal of power electronic equipment.

For a healthy grid case, grid voltage, grid impedance and control parameters are summarized in the vector $\mathbf{a}\left(T_{0}\right)$. The trajectory of power electronic equipment is the green curve $\eta\left(\boldsymbol{a}\left(T_{0}\right)\right)$. The power electronic equipment operates with its initial stable equilibrium point SEP.

In a fault case, the grid voltage and grid impedance change, denoted as vector $\mathbf{a}\left(T_{1}\right)$ and the trajectory is the red curve $\eta\left(\boldsymbol{a}\left(T_{1}\right)\right)$. Since the trajectory $\eta\left(\boldsymbol{a}\left(T_{1}\right)\right)$ does not have a stable equilibrium point, the operating point moves along the red curve, which means that in the fault state, the power electronic equipment is in an unstable state.

Between the healthy grid case and the fault case is the critical grid case, the grid voltage and grid impedance change, denoted as vector $\boldsymbol{a}\left(T_{2}\right)$ and the trajectory is the orange curve $\eta\left(\boldsymbol{a}\left(T_{2}\right)\right)$. The SEP and the USEP of this state shrink together. Therefore, its operating point can be stable at CSEP when it is steady state, but it will lose stability when it is slightly disturbed.

By analyzing of the phase portrait of nonlinear system, a parameter vector $\mathbf{a}(\mathrm{t})$ can be obtained. Based on the parameters of this vector, test cases for power electronic equipment can be given.

\subsection{Stability analysis methods}

Although a well selected test case can reproduce a wide range of fault scenarios, it still has its limitations. For example, power electronic equipment can become unstable due to interaction with grid impedance resonances. So still a subset of a few test cases cannot cover all possible resonance frequencies. In addition, for stability

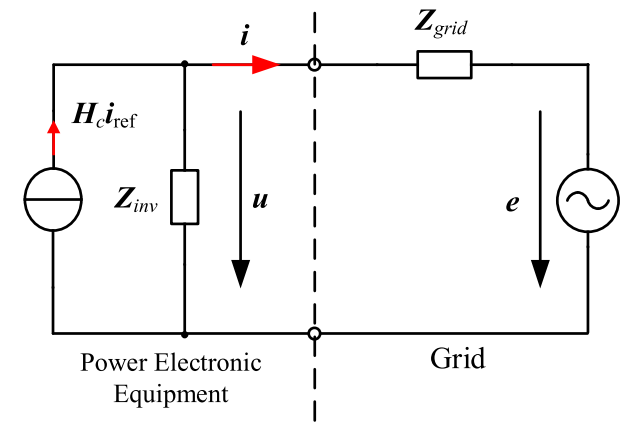

Fig. 6. Equivalent circuit diagram of a power electronic equipment-power system

evaluation, limited by computing power, test cases for large-scale power systems cannot be simulated in real time, or be simulated effectively in offline. Therefore, a stability evaluation method that does not rely on the test cases is needed. This section will introduce the analysis methods of local stability and global stability.

\subsubsection{Local stability analysis method}

An equivalent circuit diagram of a power electronic equipmentpower system based on the current source model [47] is shown in Fig. 6.

In Fig. 6, the power electronic equipment on the left is composed of a controlled ideal current source $\boldsymbol{H}_{c} \boldsymbol{i}_{\text {ref }}$ and a parallel impedance $\boldsymbol{Z}_{\text {inv, }}$ and the power system on the right is composed of an ideal voltage source $\boldsymbol{e}$ and a grid impedance $\boldsymbol{Z}_{\text {grid. }}$. Its stability can be obtained by applying the Nyquist stability criterion to the open-loop transfer function from grid impedance and parallel impedance of power electronic equipment [48]. For a power system with multiple power electronic equipment, such as a small scale system, by extending this model in Fig. 6, the above stability analysis method can be directly applied [49-51].

This analysis method is based on the frequency domain, so not computational expensive time domain simulations are needed. It is comparatively easy to evaluate stability of large scale system.

In practice, the parallel impedance of power electronic equipment can be obtained by the frequency sweep measurement of the actual power electronic equipment $[52,53]$.

However, the frequency domain based analysis methods are only suitable for the analysis of local stability, the global stability analysis needs to rely on other methods, e.g. well established Lyapunov stability criterion.

\subsubsection{Global stability analysis method}

The global stability analysis method analyzes the system's domain of attraction [26, 27], as shown in Fig. 7. This methods quantitively investigates the parameter range of both the converter controller and the grid situation which yields a stable behaviour of the power electronic device in case of a defined grid fault. The system's domain of attraction can be obtained e. $\mathrm{g}$. by time-domain simulation or Lyapunov's direct method [31]

The time-domain simulation method numerically solves the system's differential equations, then draws a trajectory accordingly and obtains a domain of attraction by checking if the trajectory remains bounded. This method has a wide range of applications and is used to analyze the global stability of complex systems. However, because the time-domain simulation method requires stepwise iterative solution of differential equations, for high-order complex systems, computational effort is very high, especially if a wide range of param- 


\begin{tabular}{lll}
\hline Method & Analysis range & Application \\
\hline Frequency-domain analysis & local & single to large-scale power systems in steady-state \\
Time-domain simulation & global & single to large-scale power systems across time-scales \\
Lyapunov's direct method & global & complex power systems with selected time-scale \\
\hline
\end{tabular}

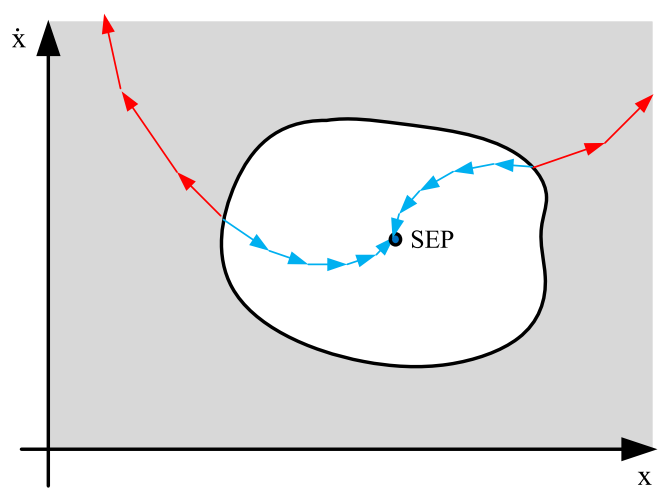

Fig. 7. Domain of attraction, all initial operating points will converge to SEP in the white area, which is called Domain of attraction (DOA)

eters need to be investigated. This rules out this method for the standardized stability evaluation process.

The second widely applied method, called Lyapunov direct method, determines the global stability by constructing a system's Lyapunov function. For a specific system to be investigated, consisting of specific grid situation and a specific set of control parameters, it can be checked if the reaction to a fault leads to a stable behaviour of the power electronic device. A specific calculation of the domain of attraction needs to be done using sophisticated mathematical methods in order to achieve results in a practical satisfactorily time. As state of the art, convex programming based on sum-of-squares programming is used [54].

Here is a summary of the three stability evaluation methods that does not rely on the test cases, as shown in Table 1.

\section{Stability evaluation and test platform for power electronic equipment}

\subsection{Evaluation and test platform}

The evaluation and test platform consist a controller hardware-inthe-loop test system [42] and a power hardware-in-the-loop test system [43].

In the controller hardware-in-the-loop test, the power hardware of the power electronic equipment, and the power system are simulated in real-time by a high-performance processor. The control step and switching period of the controller of the power electronic equipment are on sideband signal time-scale $(<1 \mathrm{~ms})$. Therefore, the step size of real-time simulation should be far less than $0.001 \mathrm{~s}$. Implementing a simulation step of one microsecond is the basic requirement of a controller hardware-in-the-loop test. The setup of a controller hardware-in-the-loop test system based on Starsim HIL system $[55,56]$, is shown in Fig. 8.

In the power hardware-in-the-loop test [43], power systems and mechanical systems are simulated in real-time by high-performance processors. The power system has practically no interaction with power electronic equipment on the sideband signal time-scale, so

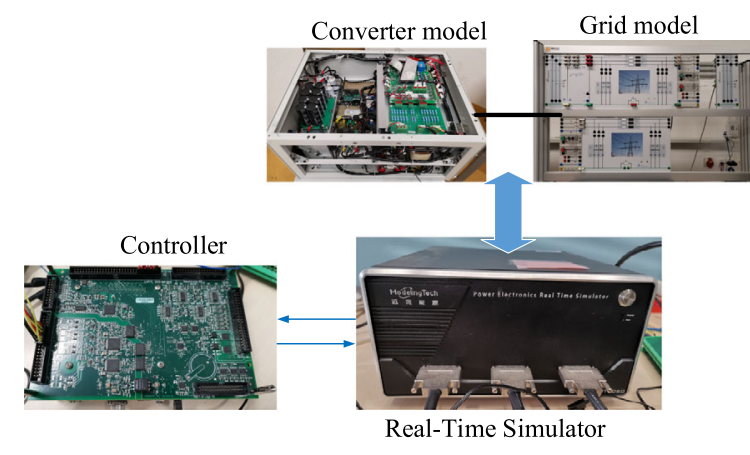

Fig. 8. Controller hardware-in-the-loop test system

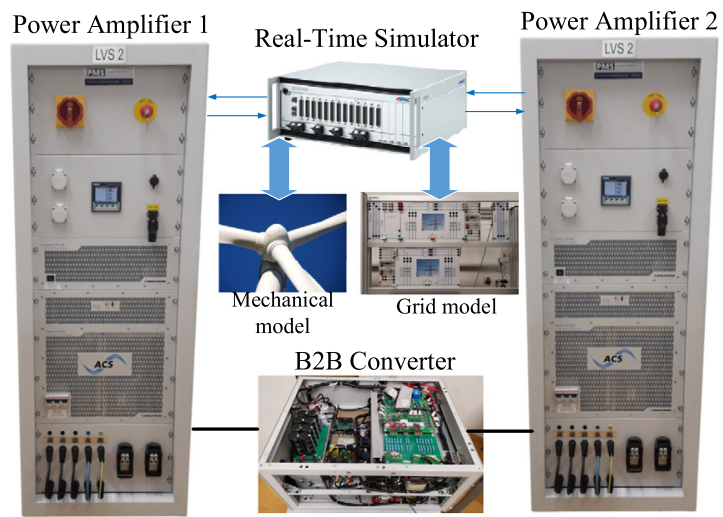

Fig. 9. Power hardware-in-the-loop test system

the real-time simulation step size can be in the range of $0.001 \mathrm{~s}$. The output signal of the real-time simulation is amplified through power amplifiers. The total delay of the power hardware-in-the-loop test, that is, the delay of the power amplifier plus the delay of the real-time simulator should be less than $0.1 \mathrm{~ms}$ [57]. The setup of a power hardware-in-the-loop test system is shown in Fig. 8.

In Fig. 9, a three-phase back-to-back converter is the equipment under test. Its grid-side converter uses the Grid Following concept. Its control strategy is the vector oriented control [48] based on synchronous reference frame phase-locked loop [25], and the reference current is provided by DC voltage control loop and reactive power control loop. Its generator-side converter is connected to a wind turbine model, which is simulated in real-time via power amplifier 1. Its grid-side converter is connected to a grid model, which is simulated in real time via power amplifier 2

\subsection{Application of platform}

In this paper, the stability evaluation and test of the grid-side converter of a wind turbine are carried out according to the evaluation and test process shown in Fig. 3. In particular, the following steps are carried out: 


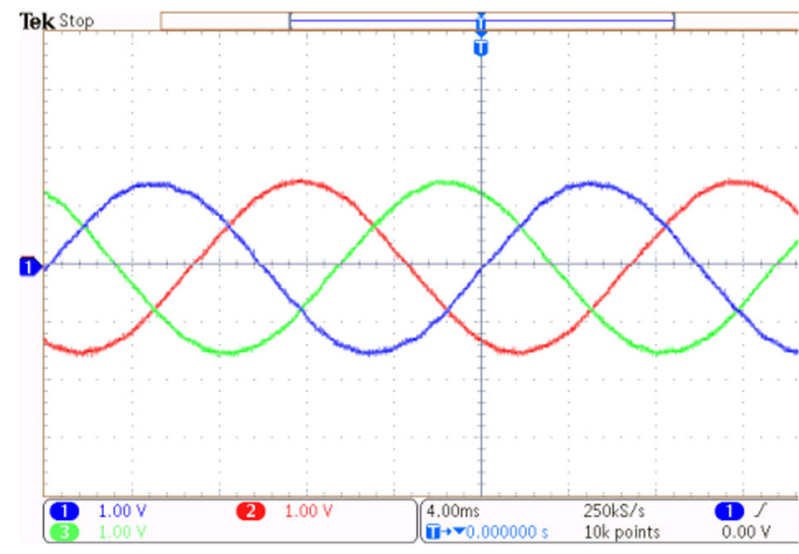

Fig. 10. Output current waveform using WVFF (Color figure online)

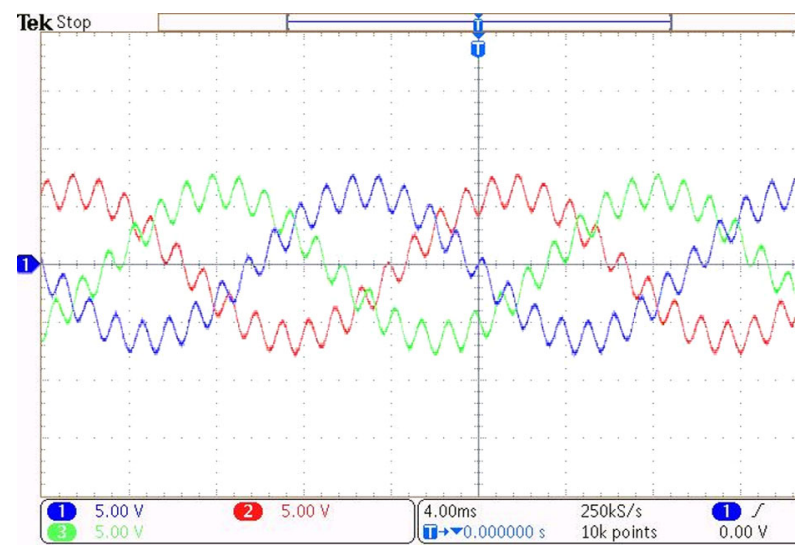

Fig. 11. Output current waveform using WOVFF

1. The pre-evaluation process based on controller hardware-inthe-loop test is performed with a representative test case. The actual information of the converter is obtained through the frequency sweep test.

2. Then, this converter is tested for global stability based on power hardware-in-the-loop.

3. Through the results of the above tests, the model of the converter is verified, and the verified model is used for local and global stability evaluation.

In the controller hardware-in-the-loop test, the converter is connected to the step-up transformer through an 80-meter cable and then connected to the medium-voltage grid through a $10-\mathrm{km} \mathrm{ca-}$ ble. In the test [42], two different control methods are deployed in the controller, which one with voltage feed-forward control (WVFF) and another without voltage feed-forward control (WOVFF). Figure 10 (WVFF) and Fig. 11 (WOVFF) are the current output waveforms based on the control hardware-in-the-loop test.

As can be seen from Fig. 10 and Fig. 11, the current waveform of WVFF (Fig. 10) is close to sinusoidal. The current waveform of WOVFF (Fig. 11) has harmonic components. It can be also seen from the FFT spectrum of Fig. 12, that the harmonic components of the WOVFF (red) are concentrated around $1100 \mathrm{~Hz}$. According to the above test results, the converter applying the WOVFF will resonate in test case.

In addition, the output admittance information of the converters of the two control methods is obtained through the frequency

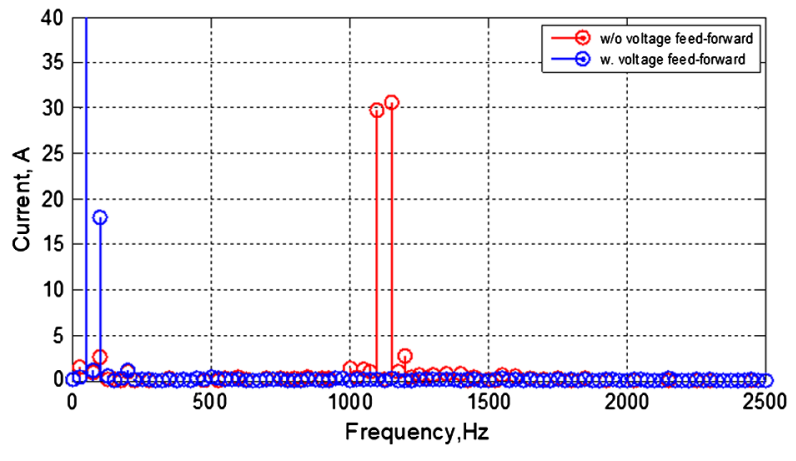

Fig. 12. FFT spectrum of output current of two control methods

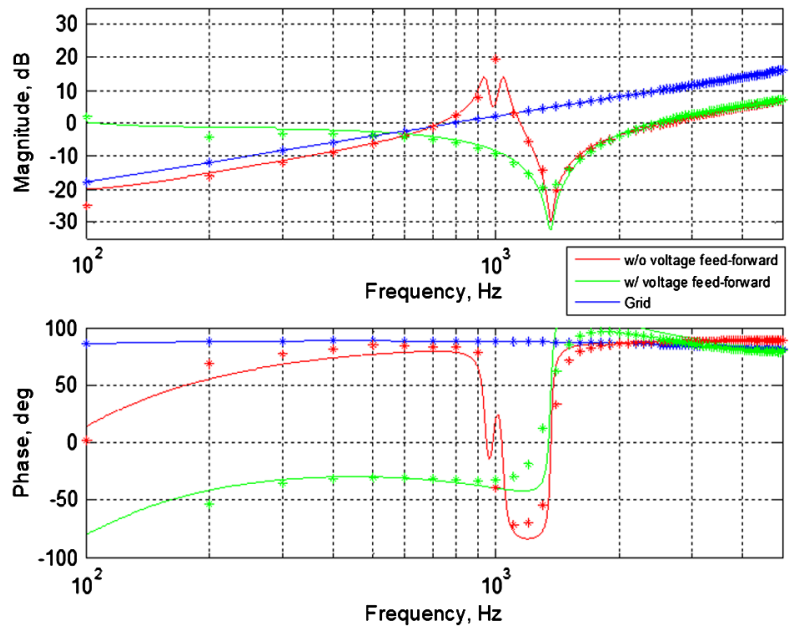

Fig. 13. Bode diagram of two control methods and power system (Color figure online)

sweep test based on the controller hardware-in-the-loop test, as shown in Fig. 13

In Fig. $13, " *$ " is the impedance information obtained by frequency sweep test, and the solid line is the impedance information obtained by modeling of the converter in the form of a current source. The accuracy of the model is evaluated through the frequency sweep test. Based on the verified model, a credible local stability evaluation can be performed.

In Fig. 13, the output impedance (green curve) of WVFF intersects the grid impedance (blue curve) at $550 \mathrm{~Hz}$, and the phase difference is 118 degrees. This means that the system stability has sufficient phase margin. This system should be stable. This can be verified in Figs. 10 and 12 .

The output impedance of the WOVFF (red curve) intersects the grid impedance (blue curve) at $700 \mathrm{~Hz}$ and $1100 \mathrm{~Hz}$, and the phase difference is 9 degrees and 167 degrees. This means that the system does not have enough phase margin at $1100 \mathrm{~Hz}$. In actual operation, the system should be in a critically stable state. This can be verified in Figs. 11 and 12. It is confirmed in Fig. 13 that the harmonic current is concentrated at $1100 \mathrm{~Hz}$, which is consistent with the results of the model evaluation.

In the global stability test, the test case is a dynamic local area power system. During the test, a three-phase ground fault occurred in the power system, which caused a voltage drop. Figures 14 and 15 show the voltage and current output waveforms based on the power hardware-in-the-loop test. 

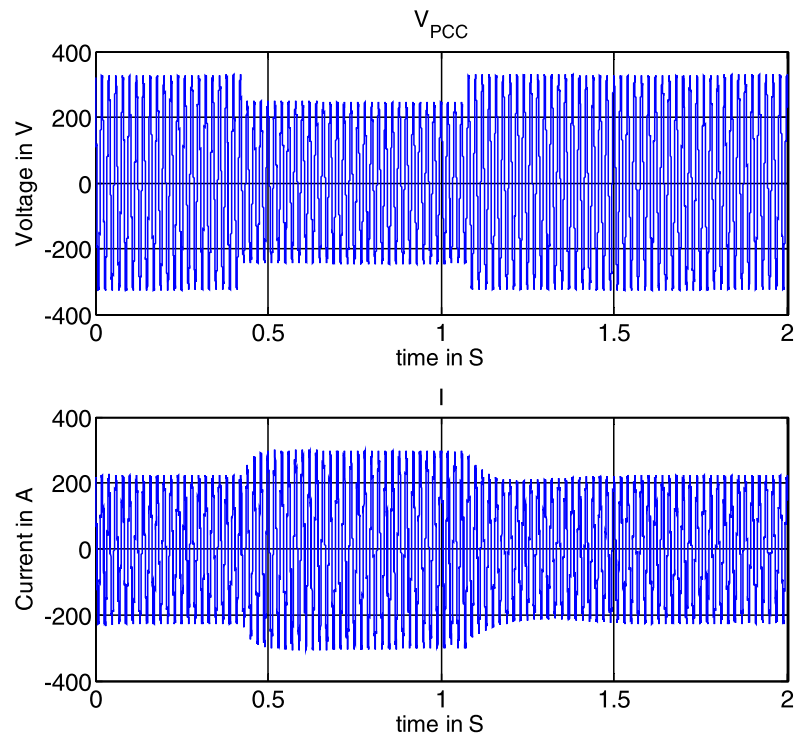

Fig. 14. Output voltage and current waveform by high fault impendence

In Fig. 14, the converter can continue to operate stably when a fault with high fault impedance occurs and after the fault is cleared, so in this case, the converter is stable. On the other hand, after clearing a low impedance fault, as shown in Fig. 15, the converter cannot return to a stable operation point. The output current goes to zero in about 0.3 seconds after the fault is cleared, which means the converter stops operating and trips. The reason for this unwanted behaviour is the loss of stability of the internal control of the power electronics control circuit. The evaluation of the model using domain of attraction methods also confirms this behaviour, as shown in Fig. 16

The color block in Fig. 16 is the domain of attraction after the fault is cleared, which is obtained by the time-domain simulation method. The area surrounded by the two upper and lower blue curves is the domain of attraction obtained by the sum-of-squares programming method. By using of the time-domain simulation method, the calculation time is about 4.5 hours. But the application of Lyapunov's direct method yields the domain of attraction in only 152 seconds, speeding up the calculation by a factor of 100 .

The color block in Fig. 16 represents the position of the solution of the system description equation when $t$ approaches infinity. The converter has a periodic stable equilibrium point $x_{\mathrm{e}} \pm n 2 \pi$. In Fig. 16, the blue circle at the origin of the coordinate is the stable equilibrium point $x_{e}$, and the green area indicates that the solution of the nonlinear differential equations will converge to the initial stable equilibrium point. The solution in the yellow area will converge to the stable equilibrium point $x_{e}+2 \pi$. The solution in the cyan region will converge to the stable equilibrium point $x_{e}-2 \pi$, and so on. The solution in the brown area is divergent, which means instability.

When the fault with high fault impedance is cleared, the system operating point is at " $A$ ". " $A$ " is within the domain of attraction and close to the initial stable equilibrium point, so after the fault is cleared, the system operating point quickly returns to the initial stable equilibrium point, as shown by the waveforms in Fig. 14.

When the fault with low fault impedance is cleared, the system operating point is at " $B$ ". " $B$ " is outside the domain of attraction, so after the fault is cleared, the system operating point is far from the stable equilibrium point, and the system is unstable, as shown by the waveforms in Fig. 15
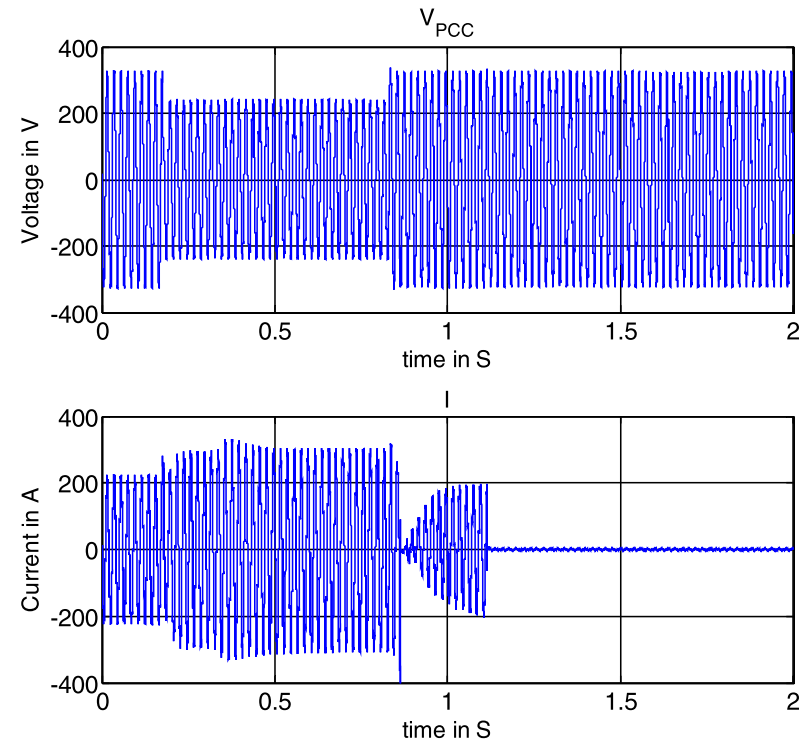

Fig. 15. Output voltage and current waveform by low fault impendence

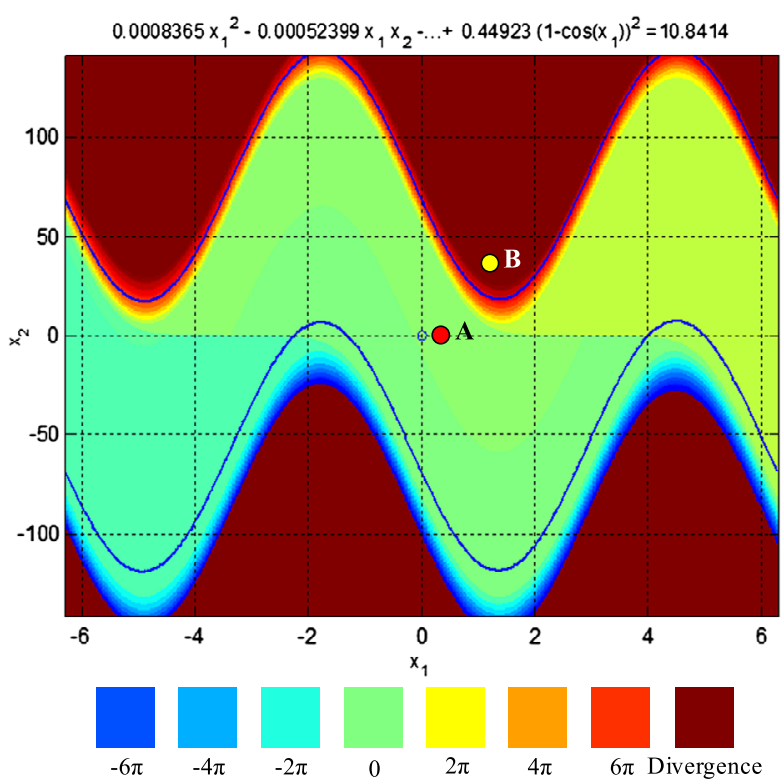

Fig. 16. Domain of attraction of power electronic equipment (Color figure online)

\section{Conclusion}

It is shown how the application of different stability measures can practically be applied to power electronic equipment connected to a power grid. The suggested process speeds up the stability compliance tests necessary for such devices and simultaneously make the evaluation and test results more credible and easier to standardize.

This paper summarizes and analyzes the complexity of stability analysis of power electronic equipment. The complexity results from the number of power electronic equipment, the time-scale of system behavior, and the range of analysis of system behavior. Based on this, a framework of three-dimensional stability analysis has been established. This framework represents the stability performance of power electronic equipment in various situations and provides support for the evaluation and testing process 
According to the framework of three-dimensional stability analysis, this paper analyzes the present type certification and stability evaluation process. The present process has room for optimization in terms of the period of process, the coverage of the selected test cases, and the credibility of the model used for evaluation. Therefore, this paper proposes a testing and evaluation process based on the concept of hardware-in-the-loop testing. The new process adds a pre-evaluation process based on the controller hardware-in-theloop, which greatly shortens the entire process. The new process uses the data of the certification test to verify the model, and combines the testing and evaluation process to enhance the reliability of the stability evaluation.

This paper studies the selection method of test cases. The analysis based on phase portrait method is used. It provides representative test cases for global stability evaluation and testing

The local stability evaluation methods proposed in this paper is frequency-domain-based stability analysis method. This greatly reduces the complexity of stability evaluation, thus leading to reduced costs for testing and evaluation. The global stability evaluation methods in this paper uses the estimation of domain of attraction based on the Lyapunov stability theory. This can rapidly obtain the Lyapunov function and the estimation of the domain of attraction from the system description equation.

Finally, based on the proposed stability evaluation and testing process, this paper evaluates and tests a power electronic equipment, including the controller and power hardware. The results of the stability test are consistent with the results of the stability evaluation.

Funding Note Open access funding provided by Graz University of Technology.

Publisher's Note Springer Nature remains neutral with regard to jurisdictional claims in published maps and institutional affiliations.

Open Access Dieser Artikel wird unter der Creative Commons Namensnennung 4.0 International Lizenz veröffentlicht, welche die Nutzung, Vervielfältigung, Bearbeitung, Verbreitung und Wiedergabe in jeglichem Medium und Format erlaubt, sofern Sie den/die ursprünglichen Autor(en) und die Quelle ordnungsgemäß nennen, einen Link zur Creative Commons Lizenz beifügen und angeben, ob Änderungen vorgenommen wurden. Die in diesem Artikel enthaltenen Bilder und sonstiges Drittmaterial unterliegen ebenfalls der genannten Creative Commons Lizenz, sofern sich aus der Abbildungslegende nichts anderes ergibt. Sofern das betreffende Material nicht unter der genannten Creative Commons Lizenz steht und die betreffende Handlung nicht nach gesetzlichen Vorschriften erlaubt ist, ist für die oben aufgeführten Weiterverwendungen des Materials die Einwilligung des jeweiligen Rechteinhabers einzuholen. Weitere Details zur Lizenz entnehmen Sie bitte der Lizenzinformation auf http://creativecommons.org/licenses/by/4.0/deed.de.

\section{References}

1. Sun, J., Li, M., Zhang, Z., Xu, T., He, J., Wang, H., Li, G. (2017): Renewable energy transmission by HVDC across the continent: system challenges and opportunities. CSEE J. Power Energy Syst., 3(4), 353-364.

2. Heffernan, M. D., Turner, K. S., Arrillaga, J., Arnold, C. P. (1981): Computation of ac-dc system disturbances-part I. Interactive coordination of generator and convertor transient models. IEEE Trans. Power Appar. Syst., 11, 4341-4348.

3. Wang, X., Blaabjerg, F. (2018): Harmonic stability in power electronic-based power systems: concept, modeling, and analysis. IEEE Trans. Smart Grid, 10(3), 2858-2870.

4. Sun, J. (2009): Small-signal methods for AC distributed power systems-a review. IEEE Trans. Power Deliv., 24(11), 2545-2554.

5. Griffo, A., Wang, J. (2012): Large signal stability analysis of'more electric'aircraft power systems with constant power loads. IEEE Trans. Aerosp. Electron. Syst., 48(1), 477-489.

6. Jalili-Marandi, V., Dinavahi, V., Strunz, K., Martinez, J. A., Ramirez, A. (2009): Interfacing techniques for transient stability and electromagnetic transient programs IEEE task force on interfacing techniques for simulation tools. IEEE Trans. Power Deliv., 24(4), 2385-2395
7. Tayyebi, A., Dörfler, F., Kupzog, F., Miletic, Z., Hribernik, W. (2018): Grid-forming converters-inevitability, control strategies and challenges in future grids application.

8. Liu, H., Sun, J. (2013, June): DC terminal impedance modeling of LCC HVDC converters. To Be Presented in 2013 IEEE 14th Workshop on Control and Modeling for Power Electronic.

9. Johnson, B. B., Dhople, S. V., Cale, J. L., Hamadeh, A. O., Krein, P. T. (2013): Oscillatorbased converter control for islanded three-phase microgrids. IEEE J. Photovol., 4(1), 387-395.

10. Pereira, H. A., Cupertino, A. F., da S.G. Ribeiro, C. A., Silva, S. R. (2013): Influence of PLL in wind parks harmonic emissions. In 2013 IEEE PES conference on innovative smart grid technologies (ISGT Latin America) (S. 1-8). New York: IEEE.

11. Taylor, C. W., Venkatasubramanian, M. V., Chen, Y. (2000): Wide-area stability and voltage control. In Proc. VII symp. Specialties electr. Oper. Expansion planning (S. $21-$ 26).

12. Qiu, Y., Xu, M., Yao, K., Sun, J., Lee, F. C. (2006): Multifrequency small-signal model for buck and multiphase buck converters. IEEE Trans. Power Electron., 21(5), 1185-1192.

13. Yuan, H., Yuan, X., Hu, J. (2017): Modeling of grid-connected VSCs for power system small-signal stability analysis in DC-link voltage control timescale. IEEE Trans. Power Syst., 32(5), 3981-3991.

14. Kurita, A., Okubo, H., Oki, K., Agematsu, S., Klapper, D. B., Miller, N. W., Younkins, T. D. (1993): Multiple time-scale power system dynamic simulation. IEEE Trans. Power Syst., 8(1), 216-223.

15. Vournas, C. D., Sauer, P. W., Pai, M. A. (1995): Time-scale decomposition in voltage stability analysis of power systems. In Proceedings of 1995 34th IEEE conference on decision and control (Vol. 4, S. 3459-3464). New York: IEEE.

16. Liu, H., Xie, X. (2018): Impedance network modeling and quantitative stability analysis of sub-/super-synchronous oscillations for large-scale wind power systems. IEEE Access, 6, 34431-34438.

17. Tao, H., Hu, H., Wang, X., Blaabjerg, F., He, Z. (2018): Impedance-based harmonic instability assessment in a multiple electric trains and traction network interaction system. IEEE Trans. Ind. Appl., 54(5), 5083-5096.

18. Li, D., Yu, Y., Jin, Q., Gao, Z. (2014): Maximum power efficiency operation and generalized predictive control of PEM (proton exchange membrane) fuel cell. Energy, 68, 210-217.

19. Chandorkar, M. C., Divan, D. M., Adapa, R. (1993): Control of parallel connected converters in standalone AC supply systems. IEEE Trans. Ind. Appl., 29(1), 136-143.

20. Alcalá, J., Bárcenas, E., Cárdenas, V. (2010): August. Practical methods for tuning PI controllers in the DC-link voltage loop in back-to-back power converters. In 12th IEEE international power electronic congress (S. 46-52). New York: IEEE.

21. Awad, H., Svensson, J., Bollen, M. J. (2005): Tuning software phase-locked loop for series-connected converters. IEEE Trans. Power Deliv., 20(1), 300-308.

22. Yepes, A. G., Freijedo, F. D., Lopez, Ó., Doval-Gandoy, J. (2011): Analysis and design of resonant current controllers for voltage-source converters by means of Nyquist diagrams and sensitivity function. IEEE Trans. Ind. Electron., 58(11), 5231-5250.

23. Teodorescu, R., Blaabjerg, F., Liserre, M., Loh, P. C. (2006): Proportional-resonant controllers and filters for grid-connected voltage-source converters. IEE Proc., Electr. Power Appl., 153(5), 750-762.

24. McGrath, B. P., Holmes, D. G. (2002): Multicarrier PWM strategies for multilevel converters. IEEE Trans. Ind. Electron., 49(4), 858-867.

25. Zhang, Z., Schürhuber, R., Fickert, L., Zhang, Y. (2018): Stability of grid-connected photovoltaic converters during and after low voltage ride through. In 8th solar integration workshop: international workshop on integration of solar into power systems.

26. Zhang, Y., Xie, L. (2016): A transient stability assessment framework in power electronic-interfaced distribution systems. IEEE Trans. Power Syst., 31(6), 5106-5114.

27. Tang, F., Wang, Q., Cen, B., Liao, Q., Liu, Y., Li, Y. (2016): A transient stability assessment method based on the trajectory in the dimension-reduced power-angle space. In 2016 IEEE power and energy society general meeting (PESGM) (Vol. pp, S. 1-5). New York: IEEE.

28. Huang, M., Wong, S. C., Chi, K. T., Ruan, X. (2012): Catastrophic bifurcation in threephase voltage-source converters. IEEE Trans. Circuits Syst. I, Regul. Pap., 60(4), 10621071.

29. Ma, M., Wang, J., Wang, Z., Khan, M. W. (2019): Global geometric structure of the transient stability regions of power systems. IEEE Trans. Power Syst., 34(6), 45954605 .

30. Choopani, M., Hosseinian, S. H., Vahidi, B. (2020): New transient stability and LVRT improvement of multi-VSG grids using the frequency of the center of inertia. IEEE Trans. Power Syst., 35, 527-538.

31. Vu, T. L., Turitsyn, K. (2015): Lyapunov functions family approach to transient stability assessment. IEEE Trans. Power Syst., 31(2), 1269-1277.

32. Kamwa, I., Grondin, R., Hébert, Y. (2001): Wide-area measurement based stabilizing control of large power systems-a decentralized/hierarchical approach. IEEE Trans. Power Syst., 16(1), 136-153.

33. BDEW Bundesverband der Energie- und Wasserwirtschaft e.V. (2008): Energieund Wasserwirtschaft e.V.: Technische Richt-linie Erzeugungsanlagen am Mittelspannungsnetz. Richtlinie für Anschluss und Parallelbetrieb von Erzeugungsanlagen am Mittelspannungsnetz. 
34. IEC 61000-4-11:2004 (2017): Electromagnetic compatibility (EMC) - Part 4-11: Testing and measurement techniques - voltage dips, short interruptions and voltage variations immunity tests

35. FGW e.V. (2014): Fördergesellschaft Windenergie und andere Erneuerbare Energien: Technische Richtlinien für Erzeugungseinheiten Teil 4. Anforderungen an Modellierung und Validierung von Simulationsmodellen der elektrischen Eigenschaftenvon Erzeugungseinheiten und-anlagen. Revision, 07 (2014).

36. TenneT TSO GmbH (2017): Offshore-Netzanschlussregeln - O-NAR.

37. Adams, J., Carter, C., Huang, S. (2012): ERCOT experience with sub-synchronous control interaction and proposed remediation. Transmission and distribution conference and exposition (T\&D), 2012 IEEE PES. New York: IEEE.

38. Buchhagen, C., Rauscher, C., Menze, A., Jung, J. (2015): BorWin1-first experiences with harmonic interactions in converter dominated grids. In International ETG congress 2015. Die Energiewende-Blueprints for the new energy age. Proceedings VDE.

39. Liu, H., Xie, X., He, J., Xu, T., Yu, Z., Wang, C., et al. (2017): Subsynchronous interac tion between direct-drive PMSG based wind farms and weak AC networks. IEEE Trans. Power Syst., 32(6), 4708-4720.

40. Gut, A., Höckel, M., Schneeberger, N., et al. (2016): Swinging grids - Messung und Modellierung von Schwingungsphänomenen in Verteilnetzen, Nidau:ESReC Grids.

41. Operator, Australian Energy Market (2016): Preliminary report-black system event in South Australia on 28 September 2016.

42. Zhang, Z., Schürhuber, R., Fickert, L., Liu, X., Chen, Q., Zhang, Y. (2019): Hardwarein-the-loop based grid compatibility test for power electronic interface. In 2019 20th international scientific conference on electric power engineering, EPE (S. 1-6). New York: IEEE.

43. Zhang, Z., Fickert, L., Zhang, Y. (2016): Power hardware-in-the-loop test for cyber physical renewable energy infeed: retroactive effects and an optimized power hardware-in-the-loop interface algorithm. In 2016 17th international scientific conference on electric power engineering, EPE (S. 1-6). New York: IEEE.

44. Code, ENTSO-E (2016): Requirements for grid connection applicable to all generators. ENTSO-E.

\section{Authors}

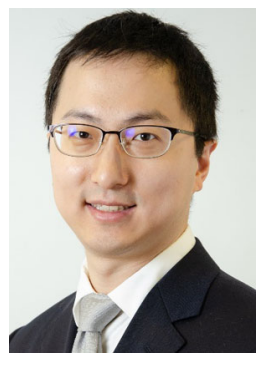

\section{Ziqian Zhang}

promovierte 2017 auf dem Gebiet der Elektrotechnik an den Technischen Universität Graz. Er ist derzeit am Institut für Elektrische Energiesysteme der Technischen Universität Graz, als Post-Doc-Forscher tätig. Seine Forschungsinteressen umfassen die Stabilitätsanalyse von leistungselektronischen Geräten und die F\&E von Hardware-in-theLoop-Testgeräten.

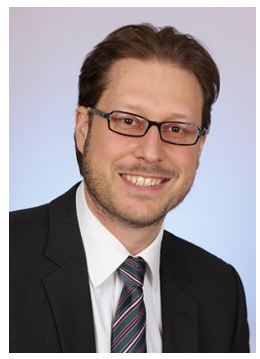

\section{Robert Schürhuber}

studierte Elektrotechnik und technische Mathematik an der Technischen Universität Wien, wo er 2002 auch auf dem Gebiet der theoretischen Elektrotechnik promovierte. Danach war er 15 Jahre in der Industrie in verschiedenen Bereichen der Energietechnik tätig, unter anderem in der Steuerung und Regelung thermischer Systeme, Erregereinrichtungen für Generatoren, Netzanbindung für die Erzeugung erneuerbarer Energien und im Bereich der Wasserkraftwerke. Im Sommer 2017 wurde er an die Technische Universität Graz berufen und leitet dort seit Oktober 2017 das Institut für Elektrische Anlagen und Netze.
45. TOR (2019): Technische und organisatorische Regeln für Betreiber und Benutzer von Netzen. e-contro.

46. VDE-AR-N 4110 (2018): Technische Anschlussregel Mittelspannung. VDE.

47. Sun, J. (2011): Impedance-based stability criterion for grid-connected converters. IEEE Trans. Power Electron., 26(11), 3075-3078.

48. Zhang, Z., Gercek, C., Renner, H., Reinders, A., Fickert, L. (2019): Resonance instability of photovoltaic E-bike charging stations: control parameters analysis, modeling and experiment. Appl. Sci., 9(2), 252

49. Lu, M., Yang, Y., Johnson, B., Blaabjerg, F. (2018): An interaction-admittance model for multi-converter grid-connected systems. IEEE Trans. Power Electron., 34(8), 75427557.

50. Gu, Y., Bottrell, N., Green, T. C. (2017): Reduced-order models for representing converters in power system studies. IEEE Trans. Power Electron., 33(4), 3644-3654.

51. Willems, J. C. (1972). Dissipative dynamical systems.

52. Guo, X., Wu, W., Chen, Z. (2010): Multiple-complex coefficient-filter-based phaselocked loop and synchronization technique for three-phase grid-interfaced converters in distributed utility networks. IEEE Trans. Ind. Electron., 58(4), 1194-1204.

53. Ciobotaru, M., Agelidis, V., Teodorescu, R. (2011): Line impedance estimation using model based identification technique. In Proceedings of the 2011 14th European conference on power electronic and applications (S. 1-9). New York: IEEE.

54. Parrilo, P. A. (2003): Semidefinite programming relaxations for semialgebraic problems. Math. Program., 96(2), 293-320.

55. Wang, K., Huang, X., Fan, B., Yang, Q., Li, G. (2018): Decentralized power sharing control for parallel-connected converters in islanded single-phase micro-grids. IEEE Trans. Smart Grid, 9(6), 6721-6730

56. Zhang, H., Liu, Z., Wu, S., Li, Z. (2019): Input impedance modeling and verification of single-phase voltage source converters based on harmonic linearization. IEEE Trans. Power Electron., 34, 8544.

57. Zhang, Z. (2016): Power hardware-in-the-loop test system. PHD Thesis, Graz University of Technoligy.

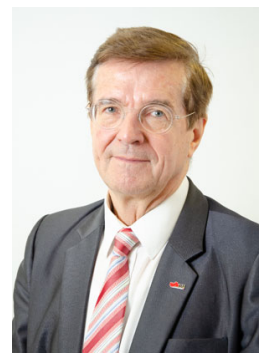

\section{Lothar Fickert}

wurde im Januar 1949 geboren und erhielt 1975 seinen Doktortitel an der Technischen Universität Wien. Er arbeitete bei ELIN UNION und BROWN BOVERI, Wien, als Inbetriebsetzungsingenieur und Projektleiter im Bereich Kraftwerke und als Schutzingenieur im Bereich Netzbetrieb bei WIENSTROM. Von 1998 bis 2017 leitete er das Institut für Elektrische Anlagen und Netze an der Technischen Universität Graz. Seit Oktober 2017 ist er emeritierter Professor und forscht weiterhin am Institut. Seine Forschungsschwerpunkte sind effiziente Nutzung elektrischer Energie, Energiequalität, Versorgungssicherheit, Erzeugung, Übertragung und Verteilung elektrischer Energie.

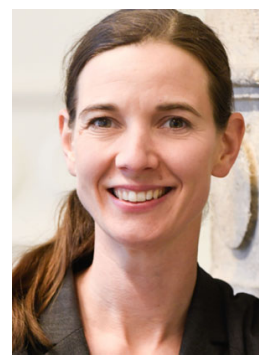

Katrin Friedl

wurde 1981 in Scheibbs, Österreich, geboren. Nach ihrem Diplomstudium der Elektrotechnik an der Technischen Universität Wien im Jahr 2005 promovierte sie 2012 an der Technischen Universität Graz. Danach arbeitete sie beim Übertragungsnetzbetreiber Austrian Power Grid AG mit den Schwerpunkten elektromagnetische Felder und Netzplanung. Seit 2019 ist sie am Institut für Elektrische Anlagen und Netze der Technischen Universität Graz beschäftigt und forscht im Bereich der niederfrequenten magnetischen und elektrischen Felder, elektromagnetischen Beeinflussungen, sowie Erdung und Sicherheit von elektrischen Energiesystemen. 


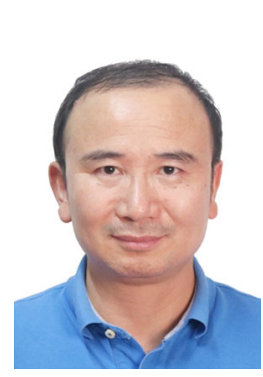

\section{Guochu Chen}

wurde im Januar 1971 geboren. Im Juni 2006 schloss er sein Studium an der East China University of Science and Technology mit einem Doktortitel in Kontrolltheorie und Regelungstechnik ab. Im April 2013 wurde inm der Professorentitel verliehen, und seit Januar 2016 ist er Dekan der School of Electrical Engineering der Shanghai Dianji University, China. Die Hauptforschungsgebiete sind Windenergieerzeugungstechnologie, Optimierungsmethoden für komplexe Systeme, Systemmodellierung und -steuerung usw.

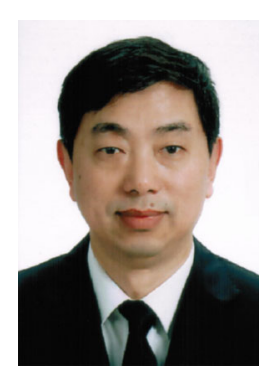

Yongming Zhang

geboren im April 1957. Er absolvierte sein Studium an der East China University of Science and Technology und beendete es im Jahr 1983. Er ist Professor an der Shanghai Dianji University und Mitglied des Unterausschusses für elektrische Ausrüstung für Windkraftanlagen des Normenausschusses für Windkraftanlagen der Energieindustrie der nationalen Energieverwaltung China. Seine Hauptforschungsrichtungen sind: die Testtechnologie für elektrische Ausrüstung von Windturbinen, Windkrafttestsysteme (Ausrüstung); die Hardware-in-the-Loop-Testtechnologie und Echtzeit-Simulation usw. 